\title{
Determination of protein level and lysine supplementation of a maize/soyabean diet for hacon pigs
}

\author{
J. CASTAING, M. LELILLET \\ Association générali des Productiors de Mais. \\ 1. placi si. de Letstapis, \\ (54001) Pau \\ Institut Technique des Céréale's it des Fourrages, \\ Y, avenue du Président Irilson. \\ \%5716 Paris
}

This study was made to examine the consequences of restricted protein feeding constant supply during both growing and finishing periods and in order to limit, by lysine supplementation, the slight lowering of performances recorded in previous trials during the growing periol.

The results obtained show the following facts:

Comparison of dietary protcin levels (1\%, 15 and 73 p. 1010)

Diets containing i 7 and is p. roo crucle protein gave the same performances for all parameters studied.

The diets containing $13 \mathrm{p}$. Ioo crucle protein did not differ from the others for the owerall growing-finishing period, but the performances recorded between 29 and $60 \mathrm{~kg}$ were lower, notably in the females. This was partially compensated for during the finishing period where the dietary lysine content was $0.65 \mathrm{p}$. 100 and the lysine/digestible energy ratio I.92.

Comparison of lysine supplementation levels.

For the whole experimental period, the three lysine supplemented diets ( 3 p. 100 crude protein in the basal diet) did not show any significant difference either between each others or in comparison with the first three ones (17, 1.5 and 13 p. Ioo crude protein).

The previously recorded lower performances during growth (CASTAING and LEUILLET, 1975) with a $1+$ p. 100 crude protein diet supplemented with lysine as compared to a is p. 100 crude protein diet were not observed in the present trial. The difference between the weights of the piglets at the beginning of the experiment might explain this result : lighter animals with higher requirements for protein would be penalized.

During the finishing period we observed that performances were reduced with increasing lysine levels, in particular in castrated males. This would inclicate the limits for use of this amino acide in low crude protein diets. 